\title{
Online Learning Problems and the Principal's Efforts to Overcome the Problems
}

\author{
Lukman Asha 1 \\ DOI: $10.35445 /$ alishlah.v13i2.932
}

Article Info

Keywords:

Online learning

processes;

Online learning

problems;

Principal's managerial role

Kata kunci:

Proses pembelajaran

daring;

Masalah dalam pembelajaran daring;

Peran manajerial kepala sekolah

\begin{abstract}
The spread of the Coronavirus (Covid-19) has brought various drastic changes to human life, one of which is the mode of learning that should be transformed into an online mode. However, the complexities of online learning leave some problems. Thus, this qualitative study aimed to investigate the online learning processes, problems, and the principal's solutions at MA Muhammmadiyah Kampung Delima, Rejang Lebong, Bengkulu Province. The principal and five selected teachers were involved as the participants. The data were garnered from interviews and observations, and the data were further analyzed using an interactive model. The findings demonstrated that the school, in general, had implemented online learning processes based on the school and teachers' existing and general competencies. However, there were some problems therein, including ineffective delivery of materials, inadequate technological facilities of students, students' lack of discipline, and unstable internet networks. To overcome such problems, the principal arranged assistance from the government to benefit from online learning and actively encouraged teachers to establish communication with parents. As an implication, the curricular contents of teacher education in the Indonesian context should be more sensitive to the discourse of TPACK. Further studies are expected to work on the principal's managerial role in online learning by involving the principles from various schools.
\end{abstract}

\begin{abstract}
Abstrak
Penyebaran virus Corona (Covid-19) telah membawa berbagai macam perubahan drastis dalam kehidupan manusia, salah satunya adalah cara belajar yang harus ditransformasikan ke mode daring. Namun, kompleksitas pembelajaran daring meninggalkan beberapa masalah. Oleh karena itu, penelitian kualitatif ini bertujuan untuk mengungkap proses pembelajaran daring, permasalahan, dan solusi kepala sekolah di MA Muhammadiyah Kampung Delima, Rejang Lebong, Provinsi Bengkulu. Kepala sekolah dan lima guru terpilih dilibatkan sebagai partisipan. Data dikumpulkan melalui wawancara dan observasi, dan data dianalisis lebih lanjut menggunakan model interaktif. Temuan menunjukkan bahwa sekolah secara umum telah menerapkan proses pembelajaran daring berdasarkan kompetensi sekolah dan guru yang ada secara general. Namun, terdapat beberapa kendala di dalamnya, antara lain penyampaian materi yang tidak efektif, fasilitas teknologi siswa yang belum memadai, siswa yang kurang disiplin, dan jaringan internet yang tidak stabil. Untuk mengatasi masalah tersebut, kepala sekolah mengatur bantuan dari pemerintah untuk memanfaatkan pembelajaran online dan secara aktif mendorong guru untuk menjalin komunikasi dengan orang tua. Implikasinya, muatan kurikuler pendidikan guru dalam konteks Indonesia harus lebih peka terhadap wacana TPACK. Penelitian lebih lanjut diharapkan dapat membahas
\end{abstract}

${ }^{1}$ Institut Agama Islam Negeri Curup, Curup, Indonesia
Email: lukman.asha@iaincurup.ac.id 
isu peran manajerial kepala sekolah dalam pembelajaran online dengan melibatkan kepala sekolah dari berbagai sekolah.

\section{INTRODUCTION}

Many drastic and sudden changes in every aspect of human life have occurred due to the Covid19 pandemic, including one in the field of education. As stated in the Minister of Education and Culture's Circular on March 24, 2020, all teachers seem to be "forced" to adapt to the conduction of teaching-learning processes to break the chain of the Covid-19 virus's spread. As such, all teachers have to be adaptive to the so-called offline-to-online transformation of learning modes. Of course, as previously stated, such a drastic change in the offline-to-online transformation of learning modes is not readily accepted by most teachers. In such a situation, only technology can support teaching and learning activities and scientific advancement.

Online learning is not a new phenomenon that emerged in certain countries during the Covid19 pandemic. However, there has been a demand in education since a decade ago, where face-to-face learning is considered traditional. Thus technological facilities and infrastructure for teaching and learning activities are required. Hernandez et al. (2018) defined online learning as learning through a computer network that provides accessibility, connectivity, flexibility, and the capacity to develop numerous kinds of learning exchanges. According to Zhang et al. (2004), integrating multimedia technology into the classroom can revolutionize how knowledge is conveyed and could be a viable alternative to the traditional classroom setting. Students and instructors can engage with one another through online collaboration, allowing them to participate in learning exchanges that would otherwise be difficult to participate in through traditional face-to-face interactions (Martin et al., 2018).

However, in a developing country like Indonesia, online learning is not accessible due to many challenges. Besides technological facilities and infrastructure, teachers' technological competencies, and teachers' and students' readiness as the online learning challenges, the challenge can also be affiliated with the school leader's or principal's managerial role. Prior studies have worked on the domains of effectiveness, alternative learning media, and teacher-student challenges of online learning. For instance, Wei et al. (2015) elucidated that in order for online learning to be effective at the implementation level, mobile devices such as smartphones or Android phones, laptops, desktop computers, tablets, and iPhones can be utilized to access information at any time and from any location, as required. Online learning has increased in popularity in education, and it is likely to continue to develop in the future as more individuals study online (Santos \& Cechinel, 2019). According to Gómez-Rey et al. (2016), the employment of mobile technology in educational institutions, particularly in the fulfillment of distance learning goals, has made a significant contribution to creating knowledge. Video, audio, and text can all be used to help with the execution of online learning projects. Students communicate through instant messaging services and smartphone applications such as WhatsApp, among other techniques in virtual classrooms. Using social media sites like Facebook and Instagram, among other channels, to promote online learning opportunities is becoming more widespread. When students use the internet, they are connected to resources (databases, experts/instructors, libraries, and so on) that are geographically separated or even far away. Albeit its convenience, online learning is not without drawbacks because instructors, lecturers, and students will always face pedagogical and technical challenges. A study conducted by Huang (2019) posed a managerial concern for educators in the context of online learning. GómezRey et al. (2016) revealed that online learning has the potential to create competing perspectives and expectations between instructors and their students, especially when it comes to assessment and evaluation. Success in online learning will be challenging if three primary conditions are not met: the utility or usefulness of the platform employed, the perceived simplicity of using the platform, and a supportive learning environment. 
It could be understood that prior studies above have been oriented towards the domains of effectiveness, alternative learning media, and teacher-student challenges of online learning. However, to the best of the researcher's knowledge, very few previous studies have worked on the school leader's or principal's managerial role in coping with online learning drastic transformation due to the Covid-19 pandemic. Hence, the present study seeks to fill this gap by focusing on the online learning processes, problems, and the principal's efforts to overcome these problems. Such a literaure gap fulfillment leads to a novelty of this study. In a nutshell, the novelty of this study is that it works on and provides comprehensive data regarding online learning processes, problems, and the principal's efforts to overcome these problems, and the aforesaid issues are packed into a single study. The educational institution taken into this study is MA Muhammadiyah Kampung Delima in Rejang Lebong Regency of Bengkulu Province.

\section{METHODS}

Anchored in the constructivist epistemology (Creswell, 2007), the present study adopted a qualitative approach to collect and analyze the focused data in this study. The reason strengthened the methodological rationale endorsed by this study that this study sought to reveal in-depth and detailed data based on the ongoing discourse rather than garner general data as the quantitative counterparts do. The purposes of the present study were, first, to investigate the processes of conducting online classes during the Covid-19 pandemic at MA Muhammadiyah Kampung Delima. Second, it was to reveal the problems teachers face in implementing online classes during the COVID-19 pandemic at MA Muhammadiyah. Third, it was to probe into the principal's efforts to overcome problems in online learning.

The principal and five teachers were purposively selected to be the participants. There were several criteria beyond their involvement. First, the principal was the major data source. Second, the five teachers were adequately experienced in teaching because they had been teaching for over five years. Third, the five teachers were easily contacted in both offline and online ways. Fourth, the principal and five teachers were voluntarily engaged in this study as the participants. The data from participants were garnered using in-depth interviews and observations. Especially for observations, the researcher conducted both offline and online observations. Traditional observations were done by visiting the participants. In the meantime, online observations were made so that the researcher joined the online groups the teachers had made for students to learn online. The researcher became a non-participant observer to detail any staging taking place in the online learning groups.

The data gathered through interviews and observations were processed using Miles' et al. (2014) interactive model, including data collection, condensation, presentation, and conclusion. As previously stated, the data for this study were gathered through a combination of interviews and online-offline observations. To facilitate data condensing and aggregation, data from the two techniques were combined and organized into themes representing the entire data set. An in-depth analysis of the data was presented alongside excerpts from interviews chosen as the representatives of the entire data set based on the topic being addressed to illustrate the findings. Aside from that, the data were summarized entirely effectively and understandably to generate an ideal conclusion.

\section{FINDINGS AND DISCUSSION}

This section presents the findings generated from the interview and observational data. To initiate the presentation, the tabulated summary of data is displayed (see table 1). Following the data summary, detailed presentation of data is given to narrate the flow of data by annotating the data sources, either from interviews or observations. After data presentation, discussions are presenting in the following without separating them from data findings. 
Table 1. The summary of data

\begin{tabular}{|c|c|c|}
\hline Online Learning Processes & Online Learning Problems & $\begin{array}{l}\text { The Principal's } \\
\text { Evercome Online } \\
\text { Problems }\end{array}$ \\
\hline $\begin{array}{l}\text { - The school informed parents or } \\
\text { students' guardians about the } \\
\text { execution of online learning. }\end{array}$ & $\begin{array}{l}\text { - Limited facilities and } \\
\text { technological mastery of } \\
\text { some teachers and students }\end{array}$ & $\begin{array}{l}\text { - Making a policy to provide } \\
\text { several funds from BOS (School } \\
\text { Operational Assistance) to } \\
\text { purchase teacher internet } \\
\text { packages }\end{array}$ \\
\hline $\begin{array}{l}\text { - The teachers prepared online } \\
\text { learning lesson plans and tools } \\
\text { (in this study, Whatsapp). } \\
\text { - The teachers created online } \\
\text { learning Whatsapp groups. }\end{array}$ & $\begin{array}{l}\text { - Insufficient teacher-student } \\
\text { interactions in online } \\
\text { learning compared to those } \\
\text { of offline learning }\end{array}$ & $\begin{array}{l}\text { - Encouraging teachers to provide } \\
\text { extra time to guide students } \\
\text { - Encouraging teachers to engage } \\
\text { students' parents or guardians } \\
\text { to help monitor students' } \\
\text { learning }\end{array}$ \\
\hline $\begin{array}{l}\text { - In Whatsapp groups, the teachers } \\
\text { explained the materials using } \\
\text { understandable language. }\end{array}$ & $\begin{array}{l}\text { - Lack of parental care to } \\
\text { support students online } \\
\text { learning (for a few cases) }\end{array}$ & $\begin{array}{l}\text { - Facilitating teachers to provide } \\
\text { in-depth guidance and control } \\
\text { for students with limited } \\
\text { technological devices }\end{array}$ \\
\hline $\begin{array}{l}\text { - The teachers established } \\
\text { interactions with students after } \\
\text { material delivery. } \\
\text { - The teachers applied formative } \\
\text { assessments using assignments } \\
\text { - The teachers instructed students } \\
\text { to confirm their assignments by } \\
\text { showing the photos of } \\
\text { assignments. } \\
\text { - The teachers graded students' } \\
\text { works and reported the results to } \\
\text { the principal. }\end{array}$ & $\begin{array}{l}\text { - Students' limited self- } \\
\text { regulated learning strategies } \\
\text { - Heavy assignments faced by } \\
\text { students }\end{array}$ & $\begin{array}{l}\text { - Encouraging teachers to } \\
\text { establish sustainable } \\
\text { communication with parents }\end{array}$ \\
\hline
\end{tabular}

\section{The Process of Conducting Online Classes during the Covid-19 Pandemic at MA Muhammadiyah Kampung Delima}

Before the school decided to implement online learning, the school had held a meeting with parents or students' guardians to clarify what online learning was and how it was technically implemented. Before beginning the learning process, an educator must prepare a lesson plan. The lesson plan was systematically structured to run as efficiently as possible (retrieved from interview data with teacher 3). This preparation took the form of written and mental preparation on educators before the start of learning (retrieved from observation data).

Based on an interview with teacher 2, the teacher completed the planning, implementation, and evaluation stages before beginning the online learning process. The teacher must prepare lesson plans and other supporting tools such as smartphones with stable internet connections during the planning stage. The teachers' lesson plans adhered to the curriculum implemented at Madrasah Aliyah Muhammdiyah Kampung Delima. Except for the opening activities, the lesson plans were, of course, unique. If teachers usually provided materials to students in person, online learning required the teachers to create online groups through online communication media, such as Whatsapp. The teachers would, later on, enter all students according to their classes into their respective groups. The learning processes continued to be held within the online groups. The teachers could explain and handle the entire learning processes in the respective groups resting upon the respective schedules. Relevant to this data's set, Lee (2021) depicted that teachers who have technological competencies will find it easier to hold the continuity of online learning processes. Teachers in the present study seem to be sufficiently competent at utilizing media that contextually meet students' 
capability of media utility. As portrayed in this study, the teachers selected the Whatsapp application as the most comfortable media that teachers and students can access.

After the teachers explained the learning materials in online classes, students who did not understand the material were welcome to ask questions (retrieved from the observation data). The teachers would answer, of course, in the previously created online study groups. The teachers' role here was critical, as the teachers must provide answers to students' questions in language that students could easily understand to digest the answers. If there were no more students who wanted to ask questions and the teachers had finished answering, the teachers would continue by assigning homework to students. The picture of the preceding data depicted what Warsah et al. (2021) emphasized in their study as the power of teacher-student interactions. Rosset (2020) elucidated that questioning and answering activities designed by teachers during learning will enhance students' critical thinking alongside providing students with a chance to dig in further information related to the materials learned. A similar case was done by the teachers in this study, in which they provided a section of leading questions or questions and answers to help students explore more beyond what was already explained.

After the online class implementation processes, the final process was evaluation, carried out through assignments given to students. Students were given time to complete assignments based on the time allotted by the teachers. Assignments were collected by taking a photo of the assignment and sending it to the teachers directly via the Whatsapp application. After all, students had collected their assignments, the teachers went through them one by one and began grading the students' work. The teachers recorded the students' grades in a report format submitted to the principal (retrieved from interview data with teacher 5). It can be interpreted that the difference between offline and online learning in terms of evaluation is only in assignment submission (Andersen, 2016).

To some extent, the acts of sending assignments signed by photos to code and inform teachers that the students' assignments had been submitted demonstrated the interactive application of multimodal theory in learning (Weninger, 2021; Yu, 2017). Regarding the evaluation processes, as portrayed in the preceding data, the teachers did the same thing as the evaluation process in traditional learning. However, it is interesting that the teachers in this study applied a formative assessment through tasking students. The essence of a formative assignment is to help teachers design better future learning (Leenknecht, 2021) and to help motivate students since a formative assessment can provide reflective feedback to students (McCallum, 2021).

The portrayed data above were also consistent with the explanation of the Principal of Madrasah Aliyah Muhammadiyah Kapung Delima as follows:

"The learning process during the pandemic is carried out online. Of course, before deciding on this, the school had already held a meeting with parents and students' guardians regarding this online learning. Of course, it also refers to the 2013 curriculum, where each teacher is asked to create a group using one of the online communication media, namely Whatsapp. Each teacher explains the materials through a written language that all students easily understand in the learning activities. Furthermore, students are invited to ask questions about things that have not been understood in their respective class groups, and the teacher answers students' questions in easy-to-understand language." (Retrieved from interview data with the principal)

As a whole, it is possible to interpret that the implementation of online learning at MA Muhammadiyah Kampung Delima was undertaken as usual, except that the teachers and students did not meet in a face-to-face mode. The learning processes utilized electronic devices, such as cellphones with some applications therein, which a stable internet connection must accompany. As a confirmative context, similar findings are also encountered in Elisvi's et al. (2020) and Warsah's (2021) studies on learning processes in Indonesia's online learning context. The observation data 
confirmed that learning generally began with greetings, prayer, and checking for students' presence. The teachers further explained the materials flexibly and in a simple language to understand. Following that, the teachers assigned tasks to students, which were collected by taking photos, and then sending them to the teachers. Subsequently, the teachers evaluated by checking one by one the photos of assignments (see Movshovitz-Attias (2016) and Weninger (2021) on multimodality) sent by students and then recording students' scores on the available report formats.

Even though the implementation of online learning, in general, seemed to work well, there were encountered some problems as well. Sometimes, the existing facilities and teachers' limited technological mastery became a problem on certain days of learning processes. According to interview data with teacher 4, due to limited facilities and technological mastery possessed by teachers and students, online learning could only be carried out through mobile applications. The internet network sometimes became one of the major hindrances. Furthermore, it seemed that the extent of online learning that was implemented went to giving written assignments via photos and, on occasion, practice via videos. Albeit the question and answer section was applied during learning, the entire communication and interactions were still deemed too limited if compared to the previous offline learning before the Covid-19 pandemic. Compared to previous offline learning, the implementation of online learning did not seem to have reached successes as much as offline learning (retrieved from interview data with teacher 4 ).

Viewed from prior studies, similar findings could be identified, especially in online learning infrastructure and facilities and teacher-student interactions. For example, Huang (2019) discovered that face-to-face courses are more noticeable than online courses regarding teachers' cognitive, emotional, and managing responsibilities. If the online mode is not correctly designed, the teacher's participation in these three responsibilities may be hidden. According to the findings of a study on teachers' and students' perceptions of online learning conducted by Gómez-Rey et al. (2016), there are different points of view. The teachers prefer and orient online learning in the collaborative learning dimension, prioritizing interactions between teachers and students and between students and students. However, students perceive that online learning with an individual orientation is more favored. Previous research has also provided an overview of the factors that must be considered for effective online learning. According to Barberà et al. (2016), several factors influence student success in online learning, including the ability to use various online learning tools, learning motivation, goals or expectations for online learning, prior knowledge, and general abilities or competencies students possess. According to the findings of Hernández-Lara and Serradell-López (2018), the success or fluency of online learning can be determined by the relationship between students' general abilities and their learning outcomes, the compatibility between learning objectives and the learning process, and the compatibility between students' expectations and their satisfaction with the learning process. These connections will significantly improve the effectiveness of online learning. According to Wei et al. (2015), increasing the number of interactive components in online learning contributes to its success. In addition, the instructor's response to student contact is another factor that influences the efficacy of online learning (Martin et al., 2018).

During interviews, teacher 5 added that because few of the students' parents worked as laborers and traders at a trim level, they could not provide their children with capable smartphones for learning. Sometimes, a few parents were also busy at work, so that they could not consistently accompany and control their students during learning processes. This also impacted students' disobedience during the online learning process (retrieved from interview data with teacher 5 ). The same condition is also portrayed in Efriana's (2021) study. Parents' economic problems can affect the quality of children's online learning because students have limited and unqualified online learning tools.

Another problem coded from interview data was that students' independence while studying at home could not be fully realized. Due to the lack of face-to-face contact between students and 
teachers, students were forced to be self-sufficient in understanding the material and completing existing assignments. This did not rule out the possibility of a material misinterpretation, especially if the material necessitated a thorough explanation (retrieved from interview data with teacher 2). It could be interpreted that the students in this study are not yet competent at self-regulated learning. Simply defined, self-regulated learning refers to students' abilities in planning, executing, monitoring, and evaluating their learning in an independent way (Bai et al., 2020; Bai \& Guo, 2018; Warsah \& Nashori, 2020). According to Warsah (2020), the role of teachers should extend to more than teaching the materials, in which teachers should also teach students how to learn independently. If reflected more profoundly, the teachers in this study are not yet competent at leading students to be independent learners. Prior studies suggested that to help students become independent learners. There are some critical constructs to be taught to students. They comprise the essences of self-efficacy (Aydogdu, 2017), metacognition (Compagnoni et al., 2019), self-regulation (Burnette \& Babij, 2020), and growth mindset (Buenconsejo \& Alfonso D. Datu, 2020). If teachers each students the aforesaid constructs besides teaching them the learning materials, the students will acquire effective strategies of learning to solve their own learning problems and pace their learning at their respective levels.

Viewed from the observation data taken in a way that the researcher joined the Whatsapp groups the teachers created for students, it could be seen that the tasks and work assigned to students by the teacher made students feel burdened, not to mention the pressure of fulfilling the teachermandated deadlines for completing assignments. Also, online learning was hampered by unstable internet networks and exorbitant prices of internet data. The location of the students' residence also had an impact on the internet connection. Some students lived in the highlands with good internet connections, but others lived in lowlands with jerky internet connections (retrieved from observation data). Relevant to the observation data, the data of interview with one of the teachers made consistent confirmation as follows:

"Because this is my first experience running an online class, several issues arise as a homeroom teacher at the same time, namely internet data and internet networks, which occasionally experience disruptions such as signal loss or running out of internet data while conducting online classes. Furthermore, some students are not disciplined enough to begin online classes, causing learning to be hampered and affecting the collection of late assignments. In addition to the two problems mentioned above, I also encountered issues such as the high price of quotas during the pandemic and some students who did not have smartphones because the average economic condition of my students was middle to lower. The students' parents worked as laborers on average and traders who could not accompany students during the learning process. Furthermore, not all students can easily understand the learning material that I explain because there is no face-to-face distribution. This has become a problem for me; I believe it is difficult because the learning process, as usual in face-to-face classes, is difficult because children sometimes do not listen and are cool on their own. Especially for nowadays, everything must be done online, including the implementation of learning at this MA." (Retrieved from interview data with teacher 3)

Not all MA Muhammadiyah teachers could make use of available information technologybased learning media. Furthermore, some teachers were still stuttering when utilizing advances in information technology as a learning medium. They were not accustomed to using the internet or other electronic media for learning, such as mobile phones, television, and radio. On the other hand, teachers were still having difficulty deciding which types of information technology-based learning media were appropriate for the materials and learning objectives that would be taught.

Communication between homeroom teachers and parents is critical to online learning success because students cannot meet face-to-face with teachers in this learning process (Bordignon, 2016). 
Hence, parents serve as the primary teachers at home (Uyun et al., 2021). Different types of parental work backgrounds make online learning less than optimal because parents cannot accompany their children when they participate in online learning, resulting in a lack of effectiveness and time efficiency in the online learning process. Teachers must be available to accompany students from morning to night. This is related to the teacher's performance, in which the teacher should prepare the material for the next day but still feels burdened by the material that was not completed that day.

Online learning is unquestionably different from face-to-face learning in the classroom. Teachers must, of course, involve parents in the implementation of online learning, as the role of parents is critical to the success of the online learning process itself (Al-Sofi, 2016). In online learning, stable signal quality and an adequate internet quota are required to support online learning success. In the perspective of educational management, planning is a critical component that must be implemented in educational institutions (Almarashdeh, 2016). Schools may struggle to achieve their desired goals if they do not plan ahead of time. Work can be more focused and clear with proper planning. Structured online learning planning can impact the success of the online learning process (Christian, 2018). The percentage of enthusiastic students participating in learning indicates the success of the online learning process. Several types of student characters depicted above are obstacles that teachers face when using information technology-based learning media. They can influence the course of the teaching and learning process, including the use of information technology-based learning media.

\section{The Principal's Efforts to Overcome Problems in Online Learning}

The researcher conducted interviews with the school principal to find out information related to the efforts to overcome the problems faced by teachers in online learning. Concerning this issue, the principal stated as follows:

"Following up on teachers' complaints regarding the problems faced during online classes regarding the use of internet data, here I made a policy to provide several funds from BOS (School Operational Assistance) to purchase teacher internet packages. This decision was taken because the Ministry of Education and Culture also recommended it. Regarding the internet connection, because this problem is beyond our control, the teacher and I also, when it occurs, provide additional time for teachers and students to discuss materials and assignments so that students and teachers do not feel burdened by this. With repetitive tasks, keep in mind that students do not just do assignments from one subject. In addition, teachers must also convey to parents that they must allocate time to accompany their children during learning. For students who do not have smartphones, the school or teachers can come to their homes to provide books related to the material or contact their parents to inform them of the assignments. Teachers must also establish good communication with parents/guardians for the sake of student discipline and also provide regular reports on student achievement to me." (Retrieved from interview data with the principal)

The researcher also conducted interviews with a homeroom teacher of class XI to strengthen the arguments presented by the previous principal's information as follows:

"I hope this problem will not only receive attention from the school but also the parents. I hope parents can be invited to work well together to be disciplined in learning and regularly check students' internet data so that it does not run out when online classes are taking place. In such a way, students do not miss the materials. Parents are also expected to check the group so that students are not late when submitting assignments." (Interview with teacher 2) 
Continuously, during interviews, the principal shared the following information as to add the previous data:

"Trying to do everything possible so that all guardians of students can guide and accompany students during the study period at home and provide motivation and enthusiasm in learning. Because teachers cannot fully guide and teach students continuously and also ask students during the learning process what are the difficulties and problems they face during learning so that students do not feel alone and bored because usually at school there are always peers who always make them enthusiastic in learning." (Retrieved from interview data with the principal)

The following interview transcript with teacher 1 was selected from the raw data to confirm the above data:

"I also communicate as much as possible with the parents to help each other while students study from home. Because usually with parents, students can be more open about what problems they face during the implementation of this online class. Also, ask students to repeat the lessons learned earlier to deepen their understanding and so that they do not quickly forget the material at that time. And I also ask parents to convey what the students have said to me so that I, as their teacher, can also understand what they are complaining about." (Retrieved from interview data with teacher 1)

There is an emphasis that the central effort of the principal's managerial role is related to the establishment of collaborative work with parents. Similar findings of parental involvement in coping with online learning have been encountered in the studies conducted by Dong (2020) and Lau (2021). If grounded like education itself, Warsah (2020b) elucidated that parents are the first teachers for children because parents are the individuals the students would imprint even since they were born. Studies conducted by Cui (2021) depicted differences in students' online learning outcomes between those monitored by parents and those left without parental monitoring. Those with parental monitoring seem to be more enthusiastic and have more self-efficacy to participate in online learning actively. Based on the findings, it is possible to be interpreted that the principal's efforts in overcoming teacher problems in the implementation of online classes in learning for teachers are by encouraging teachers to actively communicate with the students' guardians so that students are motivated to learn beyond parents' encouragement and accompaniment.

\section{CONCLUSION}

Based on the findings and discussion of this study, it could be concluded that the implementation of online learning at MA Muhammadiyah Kampung Delima runs as usual, except that the teachers do not meet face-to-face, and the online learning processes utilized electronic devices, namely cellphones. However, there are some problems identified from the online learning processes. First, the delivery of the material is only through the Whatsapp application due to limited facilities and knowledge of technology. Hence, the material delivery is, to some extent, ineffective. Second, not all students have smartphones because the economic average of students' parents is middle to lower classes. Third, because some parents mostly work as laborers and traders, they cannot accompany them during the learning process. It has an impact on students' lack of discipline during online classes. Fourth, the assignments given by the teacher to students make students feel burdened. Fifth, students suffer from an unstable internet network. In dealing with these problems, the principal arranges assistance from the government for the benefit of online learning, in addition to other efforts by the principal in overcoming the problem, namely by actively encourage teachers to build up effective and collaborative communication with students' parents or guardians so that students are motivated to learn. Such a way can also encourage parents always to accompany their 
children during the online learning process so that children do not feel lonely and are consistently enthusiastic about learning online.

Drawing upon a few data of this study that demonstrate a semi-conventional portrayal of online learning, teachers' limited technological facilities and mastery, and insufficient teacherparent collaboration, an implication can be drawn for improving today's pedagogy. Today's pedagogy, especially in the Indonesian context, should be more sensitive to enhancing teachers' TPACK (technological pedagogical content knowledge). As such, pre-service teachers in Indonesia should be well-embedded by TPACK within the curricular contents of their education because TPACK is part of their pedagogical competencies to face inevitable technological systems and environment of education, and in-service teachers should be more resilient to adapt to the urgency of TPACK.

It is recommended that further studies be conducted to work on the issue of the principal's managerial role in online learning by involving the principles from various schools, so that the data revealed can confirm or argue the present study's data. The data can reveal more comprehensive information that could be a meaningful reference for various schools in Indonesia.

\section{REFERENCES}

Almarashdeh, I. (2016). Sharing instructors experience of learning management system: A technology perspective of user satisfaction in distance learning course. Computers in Human $\begin{array}{llll}\text { Behavior, 63(Query 2021-08-04 20:59:30), 255. } & \text { 2025 }\end{array}$ https://doi.org/10.1016/j.chb.2016.05.013

Al-Sofi, B. (2016). The impact of online communication on learning English: A case study of Saudi EFL learners. International Journal of Applied Linguistics and English Literature, 5(4), 91101. https://doi.org/10.7575/aiac.ijalel.v.5n.4p.91

Andersen, P. A. (2016). Adaptive task assignment in online learning environments. ACM International Conference Proceeding Series, 13(Query date: 2021-08-05 17:40:36). https://doi.org/10.1145/2912845.2912854

Aydogdu, B. N. (2017). The predictive role of interpersonal sensitivity and emotional self-efficacy on psychological resilience among young adults. Egitim Arastirmalari - Eurasian Journal of Educational Research, 2017(69), 37-54. https://doi.org/10.14689/ejer.2017.69.3

Bai, B., \& Guo, W. (2018). Influences of self-regulated learning strategy use on self-efficacy in primary school students' English writing in Hong Kong. Reading and Writing Quarterly, 34(6), 523-536. https://doi.org/10.1080/10573569.2018.1499058

Bai, B., Wang, J., \& Nie, Y. (2020). Self-efficacy, task values and growth mindset: What has the most predictive power for primary school students' self-regulated learning in English writing and writing competence in an Asian Confucian cultural context? Cambridge Journal of Education, 1-20. https://doi.org/10.1080/0305764X.2020.1778639

Barberà, E., Gómez-Rey, P., \& Fernández-Navarro, F. (2016). A cross-national study of teacher's perceptions of online learning success. Open Learning: The Journal of Open, Distance and eLearning, 31(1), 25-41. https://doi.org/10.1080/02680513.2016.1151350

Bordignon, M. (2016). Assessment of online information literacy learning objects for first year community college english composition. Evidence Based Library and Information Practice, 11(3), 50-67. https://doi.org/10.18438/b8t922

Buenconsejo, J. U., \& Alfonso D. Datu, J. (2020). Growth and fixed mindsets about talent matter for career development self-efficacy in selected Filipino adolescents. Children and Youth Services Review, 118, 1-6. https://doi.org/10.1016/j.childyouth.2020.105470

Burnette, J. L., \& Babij, A. D. (2020). Self-regulation mindsets: Relationship to coping, executive functioning, and ADHD. Journal of Social and Clinical Psychology, 39(2), 101-116.

Christian, T. (2018). Impact of English online learning website quality to user satisfaction in Jakarta. Proceeding of 2017 International Conference on Information Management and Technology, ICIMTech 2017, 2018(Query date: 2021-08-04 16:23:51), 278-283. https://doi.org/10.1109/ICIMTech.2017.8273551 
Compagnoni, M., Karlen, Y., \& Merki, K. M. (2019). Play it safe or play to learn: Mindsets and behavioral self-regulation in kindergarten. Metacognition and Learning, 14(3), 291-314. https://doi.org/10.1007/s11409-019-09190-y

Creswell, John. (2007). Qualiitative Inquiry and Research Design. Sage.

Cui, S. (2021). Experiences and attitudes of elementary school students and their parents toward online learning in China during the COVID-19 pandemic: Questionnaire study. Journal of Medical Internet Research, 23(5). https://doi.org/10.2196/24496

Dong, C. (2020). Young children's online learning during COVID-19 pandemic: Chinese parents' beliefs and attitudes. Children and Youth Services Review, 118(Query date: 2021-08-05 20:58:48). https://doi.org/10.1016/j.childyouth.2020.105440

dos Santos, H. L., \& Cechinel, C. (2019). The final year project supervision in online distance learning: Assessing students and faculty perceptions about communication tools. Behaviour \& Information Technology, 38(1), 65-84. https://doi.org/10.1080/0144929X.2018.1514423

Efriana, L. (2021). Problems of online learning during covid-19 pandemic in EFL classroom and the solution. Journal of English Language Teaching and Literature, 2(1), 38-47.

Elisvi, J., Archanita, R., Wanto, D., \& Warsah, I. (2020). Pemanfaatan media pembelajaran online di SMK IT Rabbi Radhiyya masa pandemi covid-19. Al-Tarbawi Al-Haditsah: Jurnal Pendidikan Islam, 5(2), 16-42.

Gómez-Rey, P., Barbera, E., \& Fernández-Navarro, F. (2016). Measuring teachers and learners' perceptions of the quality of their online learning experience. Distance Education, 37(2), 146163. https://doi.org/10.1080/01587919.2016.1184396

Hernandez, A., Perera-Lluna, A., \& Serradell Lopez, E. (2018). Applying learning analytics to students' interaction in business simulation games. The usefulness of learning analytics to know what students really learn. Computers in Human Behavior, 92. https://doi.org/10.1016/j.chb.2018.03.001

Hernández-Lara, A. B., \& Serradell-López, E. (2018). Student interactions in online discussion forums: Their perception on learning with business simulation games. Behaviour \& Information Technology, 37(4), 419-429. https://doi.org/10.1080/0144929X.2018.1441326

Huang, Q. (2019). Comparing teacher's roles of F2f learning and online learning in a blended English course. Computer Assisted Language Learning, 32(3), 190-209. https://doi.org/10.1080/09588221.2018.1540434

Lau, E. Y. H. (2021). Online Learning and Parent Satisfaction during COVID-19: Child Competence in Independent Learning as a Moderator. Early Education and Development, 32(6), 830-842. https://doi.org/10.1080/10409289.2021.1950451

Lee, A. (2021). Exploring online learning modules for teaching universal design for learning (UDL): Preservice teachers' lesson plan development and implementation. Journal of Education for Teaching, 47(3), 411-425. https://doi.org/10.1080/02607476.2021.1884494

Leenknecht, M. (2021). Formative assessment as practice: The role of students' motivation. Assessment and Evaluation in Higher Education, 46(2), 236-255. https://doi.org/10.1080/02602938.2020.1765228

Martin, F., Wang, C., \& Sadaf, A. (2018). Student perception of helpfulness of facilitation strategies that enhance instructor presence, connectedness, engagement and learning in online courses. Internet and Higher Education, 37, 52-65. https://doi.org/10.1016/j.iheduc.2018.01.003

McCallum, S. (2021). The effectiveness of formative assessment: Student views and staff reflections. Assessment and Evaluation in Higher Education, 46(1), 1-16. https://doi.org/10.1080/02602938.2020.1754761

Miles, M. B., Huberman, A. M., \& Saldana, J. (2014). Qualitative data analysis: A methods sourcebook (p. 341). SAGE Publications, Inc.

Movshovitz-Attias, Y. (2016). How useful is photo-realistic rendering for visual learning? Lecture Notes in Computer Science (Including Subseries Lecture Notes in Artificial Intelligence and Lecture Notes in Bioinformatics), 9915(Query date: 2021-08-05 18:11:31), 202-217. https://doi.org/10.1007/978-3-319-49409-8_18

Rosset, C. (2020). Leading Conversational Search by Suggesting Useful Questions. The Web Conference 2020 - Proceedings of the World Wide Web Conference, WWW 2020, Query date: 2021-O8-O5 17:33:11, 1160-1170. https://doi.org/10.1145/3366423.3380193 
Uyun, M., Daheri, M., Sutarto, Nashori, F., Warsah, I., \& Morganna, R. (2021). Parenting styles in dealing with children's online gaming routines. Elementary Education Online, 2O(2), 44-53. https://doi.org/10.17051/ilkonline.2021.02.08

Warsah, I. (2020a). Islamic psychological analysis regarding to rahmah based education portrait at IAIN Curup. PSIKIS: Jurnal Psikologi Islami, 6(1), 29-41.

Warsah, I. (2020b). Learning problems of Islamic education at SMA LB of Rejang Lebong. Ta'dib: Jurnal Pendidikan Islam, 9(1), 164-174.

Warsah, I. (2021). Islamic Religious Teachers' Efforts to Motivate Students and Implement Effective Online Learning. Edukasi Islami: Jurnal Pendidikan Islam, 10(01), 383-383. https://doi.org/10.30868/ei.v10io1.1210

Warsah, I., Morganna, R., Uyun, M., Hamengkubuwono, \& Afandi, M. (2021). The Impact of Collaborative Learning on Learners ' Critical Thinking Skills. International Journal of Instruction, 14(2), 443-460.

Warsah, I., \& Nashori, H. F. (2020). Model of everyone is a teacher here: Solution to build up students' self-confidence. Jurnal Psikologi Integratif, 8(2), 1-17.

Wei, H.-C., Peng, H., \& Chou, C. (2015). Can more interactivity improve learning achievement in an online course? Effects of college students' perception and actual use of a course-management system on their learning achievement. Computers \& Education, 83, 10-21. https://doi.org/10.1016/j.compedu.2014.12.013

Weninger, C. (2021). Multimodality in critical language textbook analysis. Language, Culture and Curriculum, 34(2), 133-146. https://doi.org/10.1080/07908318.2020.1797083

$\mathrm{Yu}$, J. (2017). Deep Multimodal Distance Metric Learning Using Click Constraints for Image Ranking. IEEE Transactions on Cybernetics, 47(12), 4014-4024. https://doi.org/10.1109/TCYB.2016.2591583

Zhang, D., Zhao, J. L., Zhou, L., \& Nunamaker, J. F. (2004). Can e-learning replace classroom learning? Communications of the ACM, 47(5), 75-79. https://doi.org/10.1145/986213.986216 